\title{
DESAIN DAN IMPLEMENTASI APD SERTA ALAT BANTU PENCEGAHAN VIRUS CORONA BAGI TENAGA KESEHATAN DI PUSKESMAS BUNGUS TELUK KABUNG PADANG
}

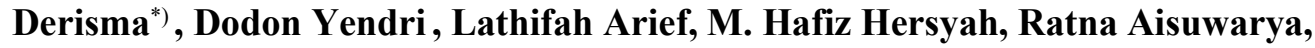 \\ Rahmi Eka Putri, Rian Ferdian, Nefy Puteri Novani, M. Ridho Heranof, \\ dan Yuni Anggraini \\ Jurusan Sistem Komputer Fakultas Teknologi Informasi Universitas Andalas \\ *)Email: derisma@fti.unand.ac.id
}

\begin{abstract}
ABSTRAK
Puskesmas adalah tulang punggung dalam menghadapi dan melawan wabah Covid-19, sebagai layanan primer yang paling dekat dengan masyarakat. Puskesmas memiliki peran yang sangat besar dan sangat diperlukan. Sebagai garda terdepan untuk penanganan corona di tingkat desa atau kelurahan, tenaga kesehatan (nakes) diharapkan tetap menggunakan Alat Pelindung Diri (APD saat memeriksa kesehatan masyarakat. Dengan ketersediaan APD, nakes akan tetap terlindungi dari risiko terkena covid19. Minimnya jumlah APD sehingga banyak petugas khususnya tenaga medis di daerah terpaksa masih menggunakan pelindung seadanya. Dari rasa peduli dan keprihatinan atas keterbatasan APD yang ada di Puskesmas Bungus Kota Padang, Jurusan Sistem Komputer Universitas Andalas Komputer berinovasi membuat APD dan Alat bantu pencegahan penularan virus corona. Metode yang digunakan dalam pelaksanaan kegiatan pengabdian kepada masyarakat adalah dengan cara membuat dan mengembangkan APD dan alat bantu pencegahan virus corona agar terlindungi dari risiko terpapar Covid-19. Alat Bantu Pencegahan dan APD dibuat bukan sekadar untuk memenuhi kebutuhan saja, tapi tetap mengutamakan protokol keselamatan keamanan serta kenyamanan bagi pemakainya. Beberapa keunggulan alat yang diserahkan yaitu tiang sterilisasi yang portable, alat bantu hand sanitizer tidak tersentuh tangan. Face Shield seperti topi dengan bahan mika bisa di pakai ulang dengan mencuci atau dilap menggunakan disinfektan. Masker hijab yang terbuat dari bahan kain spunbond yang nyaman dan waterproof sehingga aman dari cipratan droplet.
\end{abstract}

Kata Kunci: Puskesmas, Covid-19, antiseptic, disinfektan, hand sanitizer

\section{Design and Implementation of Personal Protective Equipments (PPE) and Coronavirus Infection Prevention Tools for Healthcare Professionals in Bungus Community Health Center, Teluk Kabung, Padang}

\begin{abstract}
The community health centres, or commonly known as Puskesmas in Bahasa, are the backbone for Indonesia citizens in dealing with and fighting against the Covid-19 outbreak. They are the first responders and primary services that is closest to the community. Their healthcare professionals have a very important role as the front lines that identify the symptoms at the village level. It is mandatory that they use adequate personal protective equipment (PPE) when examining people's health. With the PPE, healthcare professionals remain protected from the risk of Covid-19 exposure. The lack of PPE availability sometimes makes many officers have to use any available materials as their protection. Addressing the lack of PPE availability in a Puskesmas of a suburban area like Bungus, the Department of Computer Systems, Universitas Andalas, decides to put some innovations into practice. In this community service activity, certain PPE and sterilization tool-aids are designed and developed to protect healthcare professionals from the risk of Covid-19 exposure. Some of the types of equipment provided for the centre are portable sterilization poles, hand sanitizer tool-aids that can be used without having to be touched by hands, face shield in the form of a face-covered hat using mica material that can be reused
\end{abstract}


Website. http://hilirisasi.lppm.unand.ac.id e-ISSN: 2621-7198

by washing or wiping it using a disinfectant, and hijack-masks made from spun-bond fabric that is comfortable and waterproof.

Keywords: Covid-19, APD, antiseptic, disinfektan, hand sanitizer

\section{PENDAHULUAN}

Corona virus disease 2019 (COVID-19) menular dengan cepat ke seluruh penjuru dunia. World Health Organization (WHO) memberitahukan pada tanggal 13 Maret 2020 kasus COVID-19 ditemukan di 122 negara, dengan jumlah total 132.758 kasus confirmed dan 4.955 meninggal $(\mathrm{CFR}=3,73 \%)$. Banyaknya negara yang tertular, pada tanggal 12 Maret 2020 WHO menaikkan status COVID-19 menjadi pandemi. Di Indonesia, COVID-19 pertama kali dipublikasikan pada tanggal 2 Maret 2020 sebanyak 2 kasus, dan terus bertambah sampai pada tanggal 14 Maret 2020 jumlah kasus sebanyak 96 orang dengan 5 meninggal (Kementerian Kesehatan Republik Indonesia, 2020).

Ciri-ciri umum infeksi termasuk gejala pernapasan, demam, batuk, sesak napas dan kesulitan bernapas. Pada keadaan yang lebih berat atau parah, infeksi dapat menyebabkan pneumonia, sindrom pernapasan akut, gagal ginjal, dan meninggal. Berdasarkan dokumen resmi Kementerian Kesehatan, seseorang dapat tertular COVID19 jika menyentuh permukaan atau benda yang terkena droplet, kemudian menyentuh mulut, hidung atau mata. Virus korona baru atau COVID-19 kian meluas ke berbagai negara. Hingga kini, para ahli juga belum menemukan obat atau vaksin untuk virus yang pertama kali muncul di Wuhan, Cina tersebut (Menkes RI, 2020).

Pemerintah berupaya untuk mencegah penyebaran virus corona. Sebagai ujung tombak adalah pusat kesehatan masyarakat (puskesmas). Puskesmas adalah tulang punggung dalam menghadapi dan melawan wabah Covid-19, merupakan layanan primer yang paling dekat dengan masyarakat. Puskesmas memiliki peran yang sangat besar dan sangat diperlukan. salah satu peran Puskesmas adalah melakukan screening terhadap virus Corona. Dalam proses tersebut, metode yang dilakukan adalah melakukan penelusuran warga yang diduga melakukan kontak langsung dengan seseorang yang terjangkit Corona. Setelah Petugas Puskesmas melakukan wawancara dan penyelidikan epidemiologi, maka Puskesmas akan melakukan screening. Metode screening di Puskesmas terdapat dua cara, yakni menggunakan pemeriksaan alat rapid test antibodi dengan cara pengambilan sampel darah melalui pembuluh darah kapiler pada ujung jari tangan. Kemudian, metode yang kedua adalah melakukan swab pada tenggorokan maupun pangkal hidung. Setelah itu, lendir dari swab tersebut dibawa ke laboratorium untuk diperiksa dengan PCR. Kemudian setelah ada hasilnya, akan dilakukan informasi apakah hasilnya positif atau negatif. Pemeriksaan melalui PCR lebih tepat merupakan gold standar untuk diagnosis infeksi COVID-19, sedangkan rapid test memang lebih cocok untuk screening (World Health Organization, 2020)

Inisiatif puskesmas untuk berperan serta aktif dalam kondisi ini akan mudah terwujud dengan adanya dukungan pemerintah, salah satunya penyediaan APD, alat rapid test dan swab, yang saat ini sangat sulit didapat dan sangat mahal harganya jika hanya mengandalkan upaya masing-masing. Sebagai garda terdepan untuk penanganan 
corona di tingkat desa atau kelurahan, tenaga medis diharapkan tetap menggunakan APD saat memeriksa kesehatan masyarakat Saat ini pemanfaatan APD sangat terbatas, maka seluruh aktivitas yang ada di puskesmas sebaiknya selalu menggunakan APD, dengan menggunakan APD, tenaga medis akan tetap terlindungi dari risiko terkena covid-19

Puskesmas Bungus dan sejumlah puskesmas di Kota Padang mengeluhkan kesulitan mendapatkan alat pelindung diri (APD). Walaupun ada menggunakan APD yang tidak sesuai dengan standar Kementerian Kesehatan maupun WHO. Melihat tenaga medis dan para medis sudah banyak berkorban dalam penanganan pasien COVID-19 Jurusan Sistem Komputer muncul rasa empati terhadap tenaga medis dan para medis. Keterbatasan Alat Pelindung Diri (APD) bagi petugas medis di masa pandemi Covid-19 membuat dosen dan mahasiswa Jurusan Sistem Komputer berinovasi membuat APD dan Alat bantu pencegahan penularan virus corona. Tujuan Kegiatan Pengabdian adalah membantu Puskesmas Bungus Teluk Kabung mencegah penularan wabah COVID-19 dengan alat bantu penyemprot disinfektan dan antiseptik serta membantu dalam menyediakan APD untuk melindungi tenaga kesehatan.

\section{METODE}

Kegiatan ini dilaksanakan di Puskesmas Bungus Teluk Kabung Padang. Kecamatan Bungus Teluk Kabung Selatan terkenal dengan potensi wisata pulau seperti sungai pisang (Kabung \& Padang, 2019; Teluk et al., 2018).Kegiatan ini dilaksanakan dalam 2 tahap yaitu pertama tahap desain dan ke dua tahap implementasi.

Kegiatan ini dimulai Februari sampai akhir Mei 2020. Wilayah kerja Puskesmas Bungus merupakan bagian dari wilayah di Kota Padang dengan batas wilayah sebagai berikut : a. Sebelah utara berbatasan dengan Kecamatan Padang Selatan dan kec.Lubuk begalung b. Sebelah timur berbatasan dengan Pesisir Selatan c. Sebelah selatan berbatasan dengan Pesisir Selatan. Adapun luas wilayah kerja Puskesmas Bungus yaitu $2.730 \mathrm{~km}^{2}$ dan terdiri dari 6 (enam) kelurahan. Kelurahankelurahan yang berada dalam wilayah kerja Puskesmas Bungus yaitu Kelurahan Bungus Barat, Kelurahan Bungus Timur, Kelurahan Bungus Selatan, Kelurahan Teluk Kabung Utara, Kelurahan Teluk Kabung Selatan, Kelurahan Teluk Kabung Tengah. Jumlah tenaga kesehatan sebanyak 35 orang dengan rincian pada Tabel 1. 
Tabel 1. Jumlah Tenaga Kesehatan Puskesmas Bungus

\begin{tabular}{clccc}
\hline \multicolumn{1}{c}{ Jabatan } & $\mathbf{L}$ & $\mathbf{P}$ & $\mathbf{L}+\mathbf{P}$ \\
\hline 1 & Pejabat Struktural & 0 & 1 & 1 \\
2 & Tenaga Pendidik & 0 & 0 & 0 \\
3 & Tenaga Dukungan Manajemen & 1 & 2 & 3 \\
4 & Dr Spesialis & 0 & 0 & 0 \\
5 & Dokter Umum & 1 & 5 & 6 \\
6 & Dokter Gigi & 0 & 2 & 2 \\
7 & Dokter Gigi Spesialis & 0 & 0 & 0 \\
8 & Perawat & 0 & 6 & 6 \\
9 & Bidan & 0 & 9 & 9 \\
10 & Kesehatan Masyarakat & 0 & 0 & 0 \\
11 & Kesehatan Lingkungan & 1 & 0 & 2 \\
12 & Gizi & 0 & 2 & 1 \\
13 & Ahli Teknologi Lab Medik & 0 & 1 & 0 \\
15 & Keterapian Fisik & 0 & 0 & 2 \\
16 & Keteknisian Medis & 0 & 2 & 2 \\
17 & Tenaga Teknis Kefarmasian & 0 & 2 & 0 \\
18 & Apoteker & 0 & 0 & $\mathbf{3 5}$ \\
\hline
\end{tabular}

Sumber. Profil Kesehatan Kota Padang 2019

Metode yang digunakan dalam pelaksanaan program pengabdian kepada masyarakat adalah dengan cara membuat dan mengembangkan APD dan alat bantu pencegahan virus corona agar terlindungi dari risiko terpapar Covid.

Sedangkan alat bahan yang digunakan adalah sebagai berikut:

\section{Face Shield}

Face shield atau face mask (Kemenkes RI, 2020a)berguna mencegah penularan Covid-19 lewat droplet atau partikel air liur saat menangani pasien yang datang. Face Shield ini cara pakainya mudah seperti pakai topi, bahan mika bisa di cuci dan dipakai ulang disinfektan lalu dilap. Mika itu fungsinya menutup, tapi karena di medis tetap pakai masker di dalamnya. Face shield bisa digunakan berulang kali asalkan rutin dibersihkan. Sebelum pulang disemprot pakai disinfektan, dilap sampai kering. Besoknya kita dipakai lagi, Face shield ini cukup mumpuni guna mencegah penularan Covid-19 lewat droplet. 

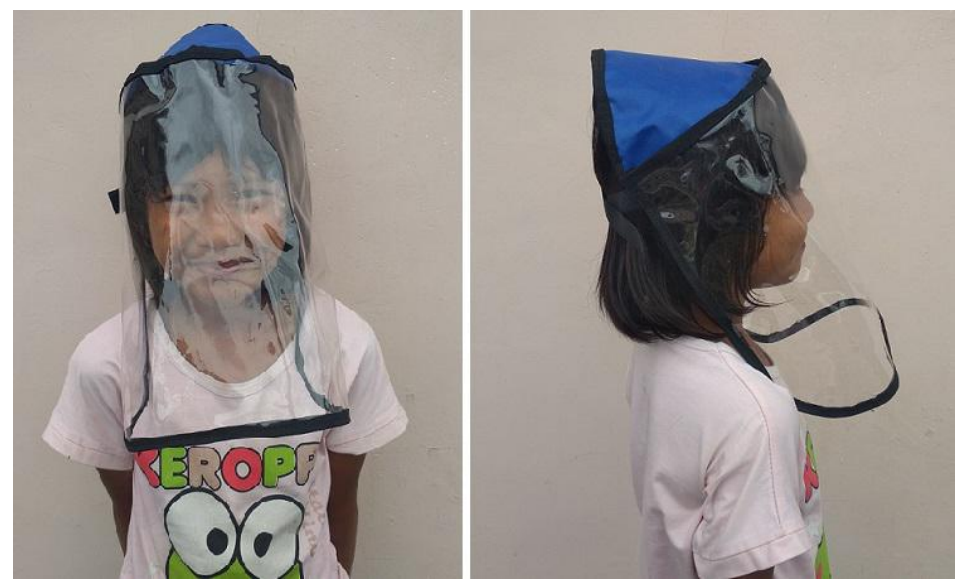

Gambar 1. Desain APD Face Shield

\section{Masker}

Tim Pengabdi memanfaatkan jasa penjahit harian yang terdampak ekonomi akibat covid-19 di Kota Padang Masker yang dibuat khusus tersebut. Masker terbuat dari bahan kain spunbond yang tebal dan nyaman saat di gunakan bahan luar (warna biru) waterproof aman dari cipratan droplet, bahan dalam (warna putih) berfungsi untuk penyaring dari luar, kain ringan tidak berat tidak sulit untuk bernapas, bahan tali gampang digunakan untuk pemakai hijab. Sehingga upaya untuk melindungi para medis dengan APD juga dapat diantisipasi (Kemenkes RI, 2020a).

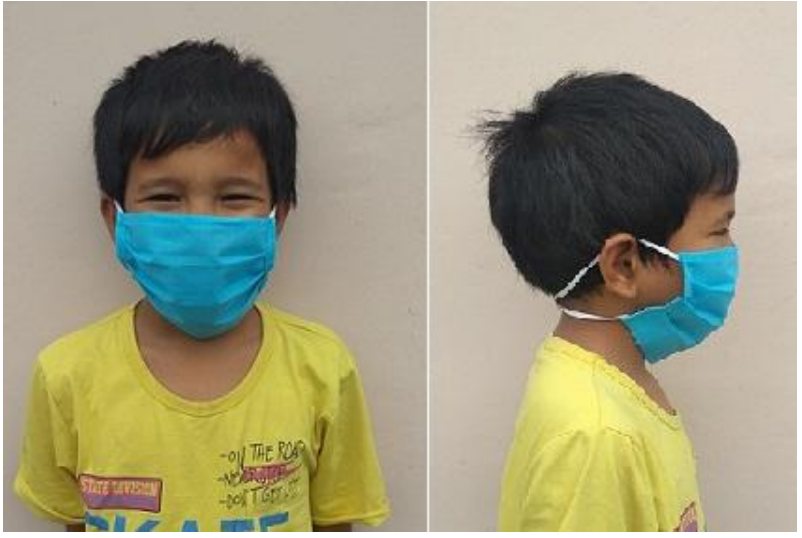

Gambar 2. Desain APD Masker

\section{Tiang Disinfektan}

Bahan untuk membuat tiang sterilisasi ini yakni besi ditambah alat semprot atau pengkabutan untuk menyemprotkan disinfektan. Sistem Penyemprotan menggunakan sprayer hampir mirip dengan prinsip sprayer untuk tanaman(Rahman \& Yamin, 2014)(Ronando \& Indasyah, 2018)(Finahari et al., 2019). Proses pembuatannya juga tidak membutuhkan waktu lama. Tiang sterilisasi ini memiliki dua bagian, yaitu tiang itu sendiri dan bahan disinfektan yang digunakan. Bahan disinfektan yang digunakan tergantung kepada objeknya, apakah manusia atau benda mati. Jika digunakan untuk manusia maka cairan yang digunakan adalah antiseptik bukan 
disinfektan, jadi aman digunakan untuk manusia Namun, syarat cairannya harus dibuat dan dikontrol kualitasnya oleh tenaga ahli yang kompeten. Keunggulannya adalah sederhana, ringan, portable atau mudah dipindah-pindahkan. Selain itu alat yang praktis untuk membunuh kuman/virus yang menempel di tubuh tanpa repot membuka baju satu persatu, mandi dulu, kemudian pakai baju lagi. Tujuan adalah membunuh mikroorganisme yang menempel di badan atau di pakaian seseorang secara seketika. Komponen dan ukuran alat dapat dilihat pada Gambar 3.

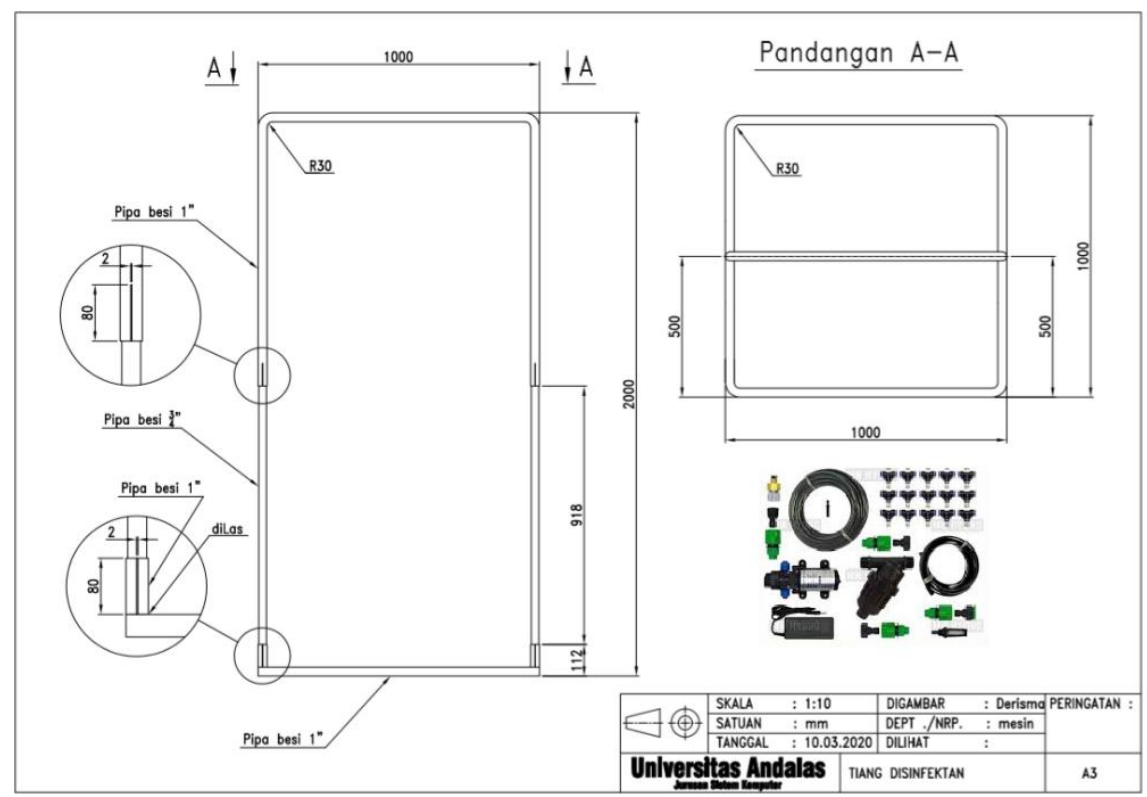

Gambar 3. Desain Tiang Disinfektan

\section{Alat Bantu Hand Sanitizer Injak}

Untuk mengurangi semakin menyebarnya virus dengan tidak menggunakan barang yang sering di pakai secara bersamaan, seperti contohnya hand sanitizer yang dipencet. Melihat setiap orang selalu menekan gagang hand sanitizer tentu hal ini perlu diwaspadai dan memiliki potensi besar untuk menularkan virus Covid-19 ini secara berantai. Dengan membuat hand sanitizer disentuh pakai kaki ini bisa meminimalisir kontak langsung tangan dengan benda-benda yang sering di pakai banyak orang. Ide ini salah satu cara agar mengurangi sentuhan terhadap benda yang sering di sentuh juga oleh orang lain. Alat ini sederhana, mudah digunakan, tidak memerlukan listrik dan aman diletakkan di tempat umum. Komponen dan ukuran alat dapat dilihat pada Gambar 4. 


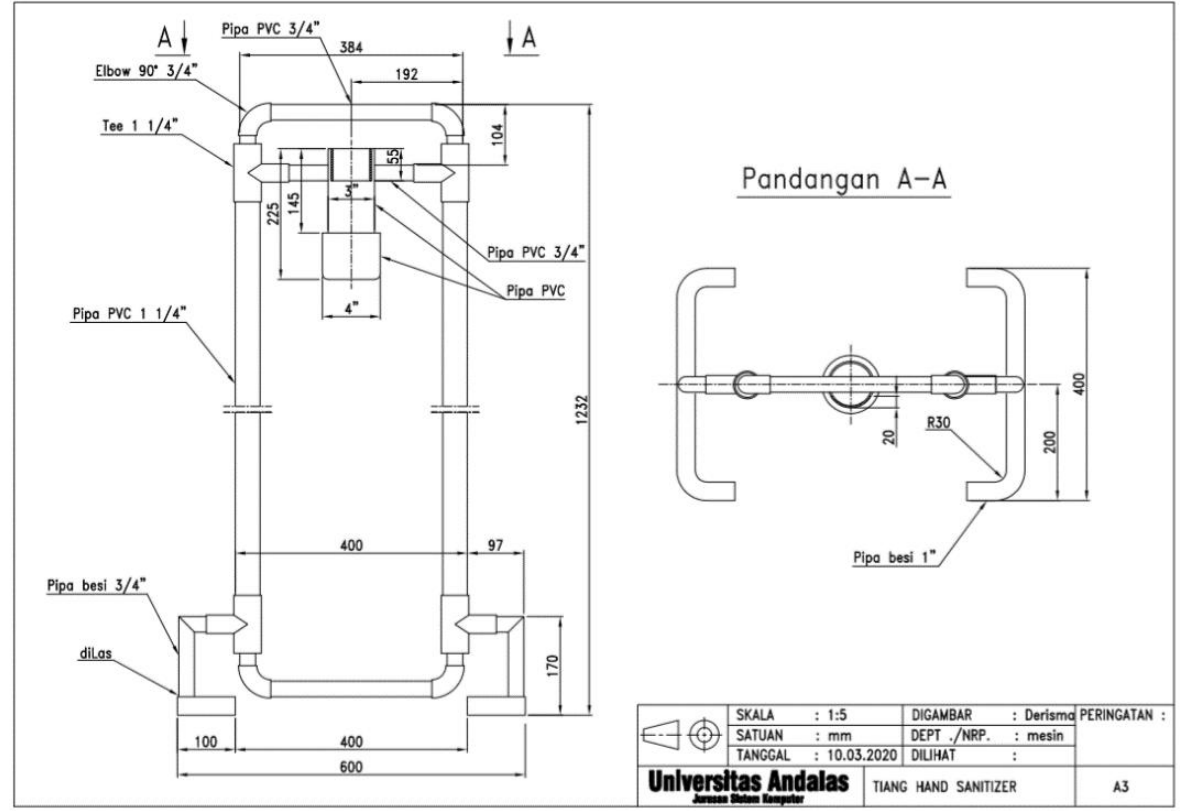

Gambar 4. Desain Hand Sanitizer Injak

\section{Antiseptik, Hand Sanitizer dan Disinfektan}

Meluasnya pandemi COVID-19 saat ini, menjadikan masyarakat menerima informasi simpang siur di dunia maya dengan adanya berbagai istilah mulai disinfektan, antiseptik, hingga bilik sterilisasi. Baru-baru ini, World Health Organization (WHO) telah memberi teguran terkait bahaya pemakaian alkohol dan chlorine pada tubuh. Banyak orang yang masih memakai istilah antiseptik dan disinfektan secara bergantian. Padahal, keduanya merupakan hal yang berbeda fungsinya. Antiseptik adalah bahan pembunuh bakteri dan virus yang digunakan di tubuh. Sementara itu disinfektan digunakan pada permukaan benda, seperti meja, gagang pintu, dan lain-lain(Kemenkes RI, 2020a).

Hand sanitizer adalah produk kesehatan yang secara instant membunuh kuman tanpa memanfaatkan air, dapat digunakan kapan saja dan dimana saja, misalnya setelah menyentuh uang, sebelum makan, setelah toilet dan setelah meninggalkan sampah. Akan tetapi pemakaian alkohol pada kulit kurang aman karena alkohol ialah pelarut organic yang dapat melarutkan sebum pada kulit, dimana sebum ini bertugas melindungi kulit dari mikroorganisme (Wijaya, 2013)

Penggunaan hand sanitizer lebih efektif dan efisien bila dibanding dengan menggunakan sabun dan air karena dapat membunuh kuman dalam waktu relatif cepat, karena mengandung senyawa alkohol (etanol, propanol, isopropanol) dengan konsentrasi $\pm 60 \%$ sampai $80 \%$ dan golongan fenol (klorheksidin, triklosan).. Alkohol juga dapat mengakibatkan kekeringan dan iritasi pada pemakaian berulang terhadap kulit serta memiliki sifat mudah terbakar (Fatimah \& Ardiani, 2018).

Oleh sebab itu, diperlukan antiseptik yang berbahan dasar alam atau yang mengandung bahan alam yang aman apabila diaplikasikan pada telapak tangan secara berulang. Ada banyak tanaman yang dapat dimanfaatkan sebagai bahan alami pembuatan hand sanitizer, yaitu daun mangga arumanis (Khaerunnisa, Riana; Priani, 
Sani; Lestrai, 2015), lidah buaya(Martono \& Suharyani, 2018), daun pandan wangi(Anindhita et al., 2020), bunga lavender(Astuti et al., 2017), buah jeruk nipis[(Paul M. Muchinsky, 2012), daun kemangi(Rohmani \& Kuncoro, 2019), daun jambu air(Simatupang, 2018), kulit jeruk purut(Dewi \& Yunianto, 2016) dan daun sirsak (Widyawati et al., 2017).

\section{HASIL DAN PEMBAHASAN}

Alat ini terdiri dari 4 macam yaitu tiang sterilisasi, face shield, masker dan hand sanitizer injak. Material yang mudah didapatkan yakni besi, paralon, plastik mika, kain spunbond anti bakteri dan anti air. Bahan ini memang sederhana, namun sudah mendapatkan rekomendasi dari pakar kesehatan sebab fungsi dan manfaatnya sama untuk pencegahan corona. Pembuatannya melibatkan masyarakat yang terdampak krisis ekonomi akibat covid-19.

Perancangan dan pengujian alat melibatkan mahasiswa yaitu Ridho Heranof dan Yuni Anggraini selanjutnya implementasinya dengan memberdayakan pengrajin besi dan penjahit yang terdampak akibat Covid 19 di kota Padang sehingga alat ini dapat tercipta. Bahan untuk membuat tiang sterilisasi ini cukup sederhana yakni besi ditambah alat semprot atau pengkabutan untuk menyemprotkan disinfektan. Proses pembuatannya juga tidak membutuhkan waktu lama. Tiang sterilisasi ini memiliki dua bagian, yaitu tiang itu sendiri dan bahan disinfektan yang digunakan. Bahan disinfektan yang digunakan tergantung kepada objeknya, apakah manusia atau benda mati.

Beberapa keunggulan alat yang diserahkan yaitu tiang sterilisasi yang portable, alat bantu hand sanitizer tidak tersentuh tangan, cukup injak paralon di bawah, maka paralon atas akan menekan tutup botol hand sanitizer. Kalau pakai hand sanitizer hanya membersihkan tangan. Namun, dengan ditambahkan tiang sterilisasi disinfektan maka seluruh tubuh dibersihkan sehingga badan benar-benar bersih dari berbagai virus dan kuman. Video demo alat dapat dilihat pada youtube, https:/www.youtube.com/watch?v=wj7ehXjUo88\&feature=youtu.be 


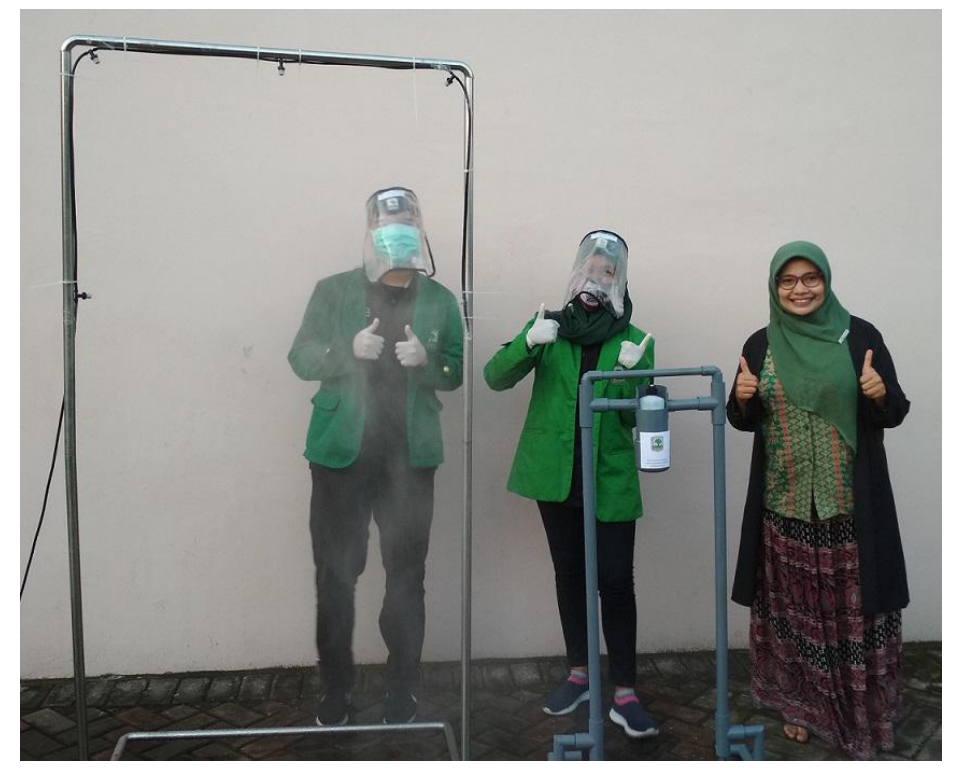

Gambar 5. Implementasi Alat Bantu dan APD

Hari Selasa pada tanggal 5 mei 2020, alat pengabdian diserahterimakan Derisma, MT dan Mohammad Hafiz Hersyah, MT kepada kepala Puskesmas dr.Fitrianti Adnan bertempat di Puskesmas Bungus Teluk Kabung, disaksikan Sekretaris Jurusan Sistem Komputer, Dr. Eng. Rian Ferdian, Ketua BAPEM Fakultas Teknologi Informasi, Dodon Yendri, M.Kom, Pembina Himpunan Mahasiswa Sistem Komputer, Lathifah Arief, MT dan Kepala Laboratorium Sinyal Sistem, Nefy Puteri Novani, MT. Bantuan APD ini terdiri dari 190 Masker dan 10 Face Shield, selain itu juga diserahkan hasil inovasi dosen dan mahasiswa Jurusan Sistem Komputer FTI Universitas Andalas berupa satu Tiang Sterilisasi dan satu Hand Sanitizer Injak. Beberapa poin yang perlu diperhatikan saat menggunakan alat ini antara lain(Kemenkes RI, 2020b):

a) Memastikan bahan yang disemprotkan ke pengguna adalah aman, tidak memiliki efek samping, tidak iritan dan tidak berpotensi berbahaya dikemudian hari. Akan sangat berbahaya jika bahan yang disemprot adalah desinfektan kimia berbahaya dan dibuat berukuran sangat kecil. Efek jangka panjangnya adalah rusaknya jaringan paru bahkan berpotensi menimbulkan kanker di kemudian hari.

b) Memastikan daya bunuh dari zat yang disemprotkan ke pengguna mampu membunuh kuman atau virus yang ada. Karena jika benefit (keuntungan) yang didapat lebih rendah dari risiko (kerugian) maka sebaiknya tidak menggunakan zat tersebut.

c) Setelah keluar dari spray diberikan pendidikan bahwa pengguna masih bisa terpapar oleh lingkungan sekitar (tidak aman/tidak steril), dan ada baiknya karena tangan tetap menjadi sumber penularan yang paling efektif maka disediakan sarana hand sanitizer injak agar tidak terjadi overconfidence dari pengguna karena kuman atau virusnya masih ada di tangan pengguna. 


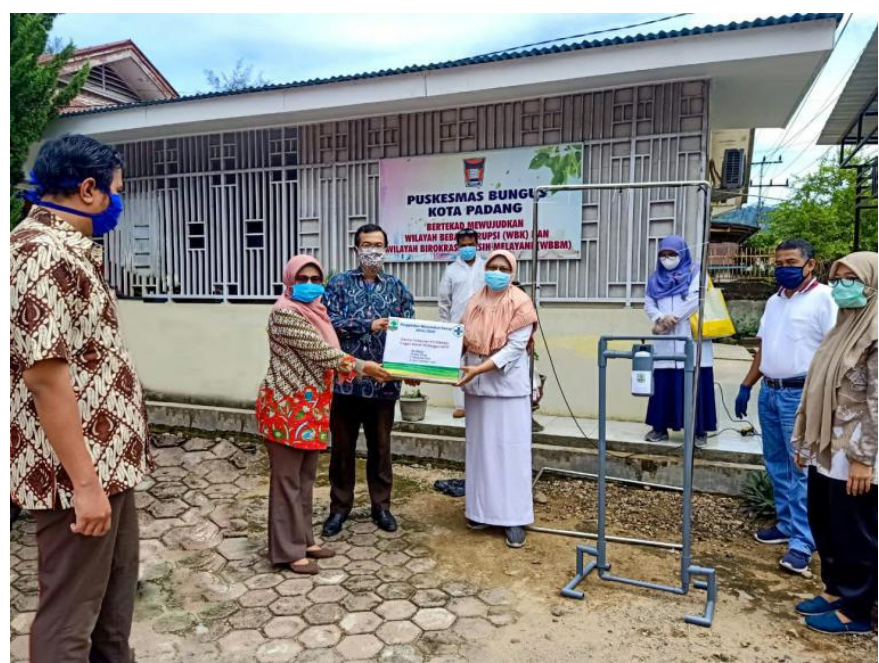

Gambar 6. Serah Terima Alat kepada Kepala Puskesmas

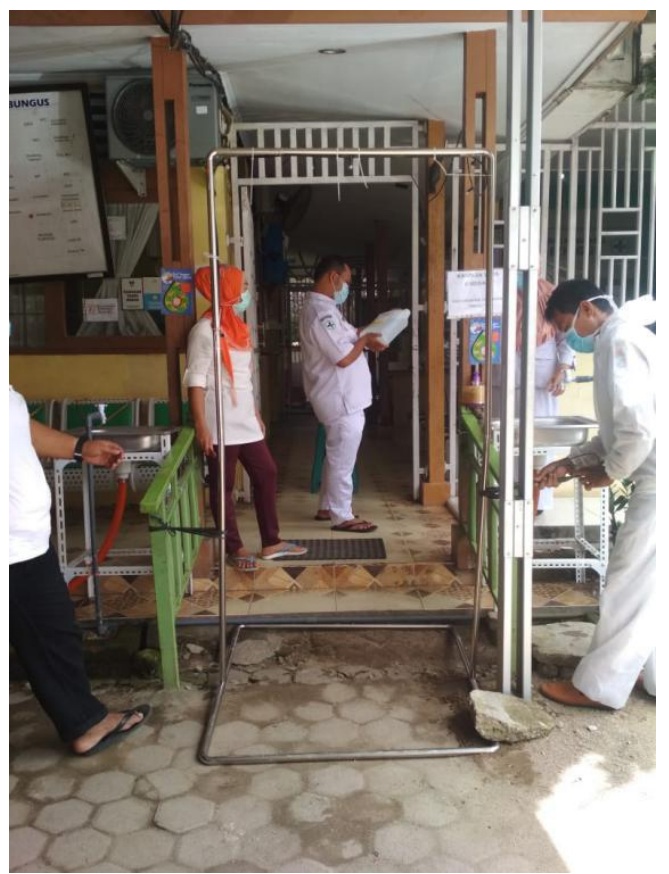

Gambar 7. Pemasangan Tiang Disinfektan di Pintu Masuk Puskesmas

\section{KESIMPULAN DAN SARAN}

Jurusan Sistem Komputer FTI Unand telah membuat alat bantu pencegahan virus corona dan APD bagi tenaga kesehatan Puskesmas Bungus Padang. Inovasi ini dikembangkan guna mencegah virus Corona yang sedang dan dipasang di pintu masuk Puskesmas. Alat Bantu Pencegahan dan APD dibuat bukan sekadar untuk memenuhi kebutuhan saja, tapi tetap mengutamakan protokol keselamatan keamanan serta 
kenyamanan bagi pemakainya. Tidak hanya untuk menahan Covid-19 masuk ke mulut, hidung, mata, dan anggota badan lainnya, tapi juga memenuhi syarat dari WHO maupun Kemenkes. Baik antiseptik maupun disinfektan, berperan penting dalam upaya pencegahan penyebaran infeksi COVID-19.

\section{UCAPAN TERIMAKASIH}

Penulis mengucapkan terima kasih kepada Ratna Aisuwarya, M.Eng selaku Ketua Jurusan Sistem Komputer, Dr. Ahmad Syafruddin Indrapriyatna, M.T selaku Dekan Fakultas Teknologi Informasi, Dr.-Ing. Ir. Uyung Gatot Syafrawi Dinata, M.T selaku Ketua LPPM dan Prof. Dr. Yuliandri, S.H., M.H selaku Rektor Universitas Andalas yang mendorong dosen melakukan kegiatan ini yang mengarah pada penanggulangan penyebaran Corona Virus Disaese (Covid-19). Selain itu penulis mengucapkan terima kasih untuk para rekan-rekan penjahit dan pengrajin besi yang telah berkolaborasi menghasilkan alat ini karena harus bergerilya ke toko-toko bangunan, plastik, spoonbond dan kain untuk mencari bahan baku yang terbatas di pasaran dan banyak toko tutup karena lockdown dan pembatasan sosial berskala besar (PSBB). Penulis juga mengucapkan terima kasih kepada editor harian singgalang dan tribun sumbar yang membantu memuat kegiatan pengabdian ini di media massa online sehingga kegiatan pengabdian dapat terpublikasikan kepada masyarakat.

\section{DAFTAR PUSTAKA}

Anindhita, M. A., Oktaviani, N., \& Pekalongan, U. (2020). Formulasi spray gel ekstrak daun pandan wangi sebagai antiseptik tangan. 9(1), 14-21.

Astuti, D. P., Husni, P., \& Hartono, K. (2017). Formulasi dan uji stabilitas fisik sediaan gel antiseptik tangan minyak atsiri bunga lavender (Lavandula angustifolia Miller). Jurnal Farmaka, 15(1), 176-184.

Dewi, I. K., \& Yunianto, B. (2016). Uji Efektivitas sediaan hand sanitizer kombinasi ekstrak daun kemangi (Ocimum sanctum $l$ ) dan ekstrak kulit jeruk purut (Citrus hystrix). Jurnal Kebidanan Dan Kesehatan Tradisional, 1(2), 130-135. https://doi.org/10.37341/jkkt.v1i2.74

Fatimah, C., \& Ardiani, R. (2018). Pembuatan Hand Sanitizer (Pembersih Tangan Tanpa Air ) Menggunakan Antiseptik Bahan Alami. Prosiding Seminar Nasional Hasil Pengabdian, 336-343, 336-343.

Finahari, N., Budi, K. P., \& Putra, T. D. (2019). Potensi Sprayer Otomatis sebagai Solusi Masalah Penyiraman Tanaman untuk Petani Cabe. JATI EMAS (Jurnal Aplikasi Teknik Dan Pengabdian Masyarakat), 3(1), 19. https://doi.org/10.36339/je.v3i1.184 
Kabung, T., \& Padang, K. (2019). Skrining penyakit kecacingan dan gangguan visus pada siswa sd di kelurahan sungai pisang Kecamatan Bungus Teluk Kabung Kota Padang. 2(4), 437-442.

Kemenkes RI. (2020a). Pedoman Kesiapsiagaan Menghadapi Infeksi Novel Coronavirus (2019-nCov). Direkorat Jenderal Pencegahan Dan Pengendalian Penyakit, $0-74$.

Kemenkes RI. (2020b). Pedoman pencegahan dan pengendalian coronavirus disease (Covid-19). Germas, 0-115.

Kementerian Kesehatan Republik Indonesia. (2020). Pedoman Kesiapsiagaan Menghadapi Coronavirus Disease (COVID-19). Direkorat Jenderal Pencegahan Dan Pengendalian Penyakit, 1-88.

Khaerunnisa, Riana; Priani, Sani; Lestrai, F. (2015). Formulasi dan Uji Efektivitas Sediaan Gel Antiseptik Tangan Mengandung Ekstrak Etanol Daun Mangga Arumanis (Prosiding Penelitian Sivitas Akademika Unisba (Kesehatan Dan Farmasi), 553-561.

Martono, C., \& Suharyani, I. (2018). D-3 Farmasi, Akademi Farmasi Muhammadiyah Kuningan. 3(1), 29-37.

Menkes RI. (2020). Surat Edaran No. HK.02.01/MENKES/2020 tentang Protokol Isolasi Diri Sendiri dalam Penanganan Coronavirus Diseases (COVID-19) (pp. 1-4). https://covid19.kemkes.go.id/

Paul M. Muchinsky. (2012). Psychology Applied to Work: An Introduction to Industrial and Organizational Psychology, Tenth Edition Paul, 53(9), 1689-1699. https://doi.org/10.1017/CBO9781107415324.004

Rahman, M., \& Yamin, M. (2014). Modifikasi nosel pada sistem penyemprotan untuk pengendalian gulma menggunakan sprayer gendong elektrik. Jurnal Keteknikan Pertanian, 2(1), 21957.

Rohmani, S., \& Kuncoro, M. A. A. (2019). Uji stabilitas dan aktivitas gel andsanitizer ekstrak daun kemangi. JPSCR: Journal of Pharmaceutical Science and Clinical Research, 4(1), 16. https://doi.org/10.20961/jpscr.v4i1.27212

Ronando, E., \& Indasyah, E. (2018). Penyuluhan alat sprayer elektrik bagi masyarakat petani Desa Wonodadi Wetan Kabupaten Pacitan. Jurnal ABDI, 3(2), 63. https://doi.org/10.26740/ja.v3n2.p63-67 
Simatupang, E. J. (2018). Formulasi Sediaan Gel Hand Sanitizer Dari Ekstrak Etanol Daun Jambu Air (Syzygium aqueum (Burm. F.) Alston).

Teluk, B., Selatan, K., Barat, S., Amrina, E., Kamil, I., Triha, H., Teknik, J., Fakultas, I., \& Universitas, T. (2018). Peningkatan Pemasaran Biduk Wisata Nelayan Di Sungai Peningkatan Pemasaran Biduk Wisata Nelayan Di Sungai Pisang, Bungus Teluk Kabung Selatan, Sumatera Barat. 1(3), 133-143.

Widyawati, L., Mustariani, B. A. A., \& Purmafitriah, E. (2017). Formulasi sediaan gel hand sanitizer ekstrak etanol daun sirsak (annona muricata linn) sebagai antibakteri terhadap staphylococcus aureus. Jurnal Farmasetis, 6(2), 47-57.

Wijaya, J. I. (2013). Formulasi sediaan gel. 2(1), 1-14.

World Health Organization. (2020). Saran Penggunaan Tes Imunodiagnostik di Fasyankes (Point of Care) untuk COVID-19. 8 April, Pernyataan Keilmuan, 1-4. https://www.who.int/docs/default-source/searo/indonesia/covid19/saranpenggunaan-tes-imunodiagnostik-di-fasyankes-(point-of-care)-untuk-covid19.pdf?sfvrsn=a428857b_2 